\title{
Thermogenic effect and substrate oxidation of protein from animal and plant sources in adults
}

Thermogenic effect dan oksidasi substrat dari protein hewani dan nabati pada orang dewasa

\author{
A Fahmy Arif Tsani ${ }^{1}$, Lee Myung $\mathrm{Joo}^{2}$, Kim Eun Kyung ${ }^{2}$
}

\begin{abstract}
Background: Changing nutrient source is one of the efforts to increase thermogenic effect (TEF) which may be significant for body weight reduction. Objective: The aim of this study was to investigate the effects of high protein diets using animal (chicken) and plant (tofu) sources on thermogenic effect (TEF) and substrate oxidation. Method: Ten female adults (mean age 20.8+1.2 y) participated in two isocaloric diet ingestions. Each meal provided $30 \%$ of the daily basal energy need (32/26/42\% as protein/ fat/carbohydrates, respectively). Postprandial energy expenditure was measured by indirect calorimetry. Results: There were no significant differences in TEF and substrate oxidation. The postprandial fat oxidation rate was higher than that at the preprandial state, while carbohydrate and protein oxidation rates were lower. Conclusion: No differences were observed in TEF and substrate oxidation in animal- and plant-based diets. A high protein diet could be beneficial for weight loss, but animal protein does not appear to offer superior benefits compared to plant protein.
\end{abstract}

KEY WORDS: thermic effect of food, high-protein diet, substrate oxidation, female adult

\begin{abstract}
ABSTRAK
Latar belakang: Modifikasi sumber zat gizi menjadi salah satu upaya untuk meningkatkan thermic effect of food (TEF) yang diyakini selaras dengan penurunan berat badan. Tujuan: Membuktikan efek diet tinggi protein yang berasal dari hewan (protein hewani) dan tumbuhan (protein nabati) terhadap TEF dan oksidasi substrat. Metode: Sepuluh wanita dewasa (berusia rata-rata 20,8 $\pm 1,2$ tahun) mengkonsumsi dua menu makanan yang mempunyai kalori yang sama. Masing-masing menu mengandung kalori $30 \%$ dari total kebutuhan dalam sehari (32\% protein, 26\% lemak, dan $42 \%$ karbohidrat). Postprandial energy expenditure diukur menggunakan indirect calorimetry. Hasil: Tidak ada perbedaan signifikan TEF dan oksidasi substrat, meskipun asupan menu tinggi protein hewani sedikit lebih besar dikonversikan menjadi TEF dibandingkan dengan menu tinggi protein nabati (12.6\% vs $11,39 \%$ ). Pada kedua menu, oksidasi lemak postprandial lebih tinggi daripada prepandial. Sementara oksidasi karbohidrat dan protein postprandial terukur lebih rendah. Simpulan: Diet tinggi protein memungkinkan memberi efek yang menguntungkan untuk penurunan berat badan, meskipun antara diet tinggi protein hewani dan diet tinggi protein nabati tidak menunjukkan perbedaan efek yang berarti.
\end{abstract}

KATA KUNCI: thermic effect of food, diet tinggi protein, oksidasi substrat, wanita dewasa

\section{INTRODUCTION}

Obesity has become one of the primary health concerns in the world because its prevalence has increased dramatically. The increase in the prevalence of the associated comorbidities is a significant burden on health care systems worldwide (1). Increased energy intake and decreased energy output are thought to be the two main causes of the development of a positive energy balance, which is related to obesity (2). The thermic effect of food (TEF) is one ofthe contributors to energy output, besides energy used for basal metabolism, physical activity, and non-exercise activity thermogenesis (3). TEF is the increase in energy expenditure above the resting state, which is required for the digestion and absorption of ingested food. It is the major form of thermogenesis in humans, accounting for $5 \%$ to $15 \%$ of the total daily energy expenditure (4).

The TEF of separate nutrients is highest for protein, followed by carbohydrates and fat. It has been hypothesized that different protein sources can

\footnotetext{
Correspondence: Department of Nutrition and Health, Faculty of Medicine, Universitas Gadjah Mada, Jl. Farmako, Sekip Utara, Yogyakarta 55281, Indonesia. Tel: +62274 547775; e-mail: fahmi_tsani@yahoo.com Department of Food and Nutrition, Gangneung Wonju National University,
} South Korea 
differentially affect TEF (5), but very limited data from human studies on this topic are available. Differential substrate oxidation has been reported in casein (complete protein) and gelatin (incomplete protein) (6). Conversely, protein increases satiety to a greater extent than carbohydrates or fat, and high protein meals induce a greater acute appetite suppressive effect than normal protein meals (7). Considering the possible effects of the protein source, the present study aimed to investigate the thermic effects and substrate oxidation in high protein diets with different animal- and plant based-diets.

\section{METHODS}

\section{Subjects}

The subjects were 10 healthy female university students who were enrolled at GangneungWonju National University (GWNU), Gangneung city, Gangwon Province, South Korea. The inclusion criteria were as follows: age $>18$ years, non-smoker, not pregnant or lactating, and no food allergies. Exclusion criteria included a history of metabolic or endocrine disease, taking medications regularly, and reporting more than moderate physical activity prior to measurements. The subjects were fully informed about the procedures of this study, and informed consent was obtained from each subject. This study was approved by Gangneung Wonju National University prior to implementation.

\section{Study protocols}

Two different isocaloric breakfast meals including animal- and plant protein-based diets were tested in a randomized crossover design. After an overnight fast of $\geq 9$ hours and a minimal amount of activity, the subjects were randomly assigned to the sequence of test meals. There was a washout period of $>5$ days between test days, and each test day lasted $7 \mathrm{~h}$. On the morning of the test days, the subject travelled to the Department of Food and Nutrition by car, bus, or by walking slowly and arrived at 8.30 a.m. After arriving at the laboratory, the anthropometry of the subjects was measured. Resting energy expenditure was measured after $10 \mathrm{~min}$ of bed rest. The subjects were instructed to consume the test meal within $15 \mathrm{~min}$. Over the following $6 \mathrm{~h}$, resting
Table 1. Energy content and macronutrient composition of the diets

\begin{tabular}{lcc}
\hline $\begin{array}{c}\text { Energy intake } \\
\text { \% of energy intake }\end{array}$ & $\begin{array}{c}\text { Chicken } \\
\mathbf{3 0 \%} \text { RMR }\end{array}$ & $\begin{array}{c}\text { Tofu } \\
\mathbf{3 0 \%} \text { RMR }\end{array}$ \\
\hline Carbohydrates & $42 \%$ & $42 \%$ \\
Protein & $32 \%$ & $32 \%$ \\
Fat & $26 \%$ & $26 \%$ \\
\hline
\end{tabular}

energy expenditure (REE) was measured in periods of 20 min with a 10 min break between each measurement. No additional foods were permitted for the following 6 h. For all REE measurements, the subjects remained in a supine position in an adjustable bed with their head placed under a transparent ventilated hood connected to a monitor by a tube. A documentary video was provided that could be quietly watched by the subjects.

\section{Test meals}

The two isocaloric test breakfast meals were provided to the subjects on two different days. Both of the meals were high protein diets with different sources (animal- and plant protein-based). Animal protein was represented by chicken meal, and plant protein was represented by tofu meal. Both of them were cooked and served with rice, kimchi, and a cup of water. Each meal provided $30 \%$ of each individual's basal energy need, which was determined by weight, height, and age. Table 1 describes the portion of the meal, which was composed of $32 \%, 26 \%$, and $42 \%$ energy as protein, fat, andcarbohydrates, respectively. Meals were prepared at the Nutrition Laboratory Department of Food and Nutrition GWNU. Food ingredients were weighed to the nearest $0.1 \mathrm{~g}$. Macronutrient analysis of the meal was performed using the computerized nutrient composition program Computer Aided Nutritional Analysis Program Version 3.0 (CAN Pro 3.0).

\section{Anthropometry}

Anthropometric measurements were carried out by the same investigator. The data included weight, height, body mass index, and body composition. Weight and height were measured using a digital scale and stadiometer. Weight was obtained with the subject wearing light clothing and measured to the nearest $0.1 \mathrm{~kg}$. 
Height was measured to the nearest $0.1 \mathrm{~cm}$ without shoes and socks. Body fat and skeletal muscle were measured by bioelectrical impedance analysis (Inbody720, Biospace Corp., Korea). The waist-hip ratio was determinedby measurement using a tap line, while TSF was measured using a skin-fold caliper. Body mass index (BMI), fat free mass (FFM), and body surface area were calculated by the following formula (8):

BMI $\left(\mathrm{kg} / \mathrm{m}^{2}\right)=$ body weight $(\mathrm{kg}) /[\text { height }(\mathrm{m})]^{2}$ FFM $(\mathrm{kg})=$ body weight $(\mathrm{kg})-$ fat mass $(\mathrm{kg})$ $\operatorname{BSA}\left(\mathrm{m}^{2}\right)=[$ body weight $(\mathrm{kg})] 0.425 \mathrm{x}[$ height $(\mathrm{cm})] 0.725$ $\mathrm{x} 0.007184$

\section{Resting energy expenditure and substrate oxidation}

Measurements of fasting, 6h postprandial REE, and substrate oxidation were conducted with indirect calorimetry of a TrueOne 2400 metabolic cart (Model QMC, ParvoMedics Corp., USA), which recorded the amount of $\mathrm{O}_{2}$ consumed and $\mathrm{CO}_{2}$ produced. The ventilated hood system was automatically recalibrated every five minutes during measurement.

Upon arrival at the laboratory, subjects were asked to relax for 10 minutes before measurement. The REE was measured for 20 minutes before consumption of each meal. The $6 \mathrm{~h}$ postprandial energy expenditure was measured every 30 minutes. No additional foods were permitted for the following 6 hours. For all measurements, the subjects remained in a supine position in an adjustable bed with their head placed under a transparent ventilated hood connected to a monitor by a tube. A documentary video was provided that could be quietly watched by subjects.

The REE represents an average of the full collection period, and it was calculated from the oxygen consumption and carbon dioxide production (9). The TEF of test meals was calculated as the difference of the postprandial and the fasting REE (10). The carbohydrate and fat oxidation rate were calculated using the following formula:

Protein oxidation $(\mathrm{g} / \mathrm{min})=\mathrm{REE}(\mathrm{kJ} / \mathrm{min}) \times 0.15 / 16.74$ (11)

Carbohydrate oxidation $(\mathrm{g} / \mathrm{min})=4.585 \times \mathrm{VCO}_{2}(\mathrm{~L} / \mathrm{min})$ $3.2255 \times \mathrm{VO}_{2}(\mathrm{~L} / \mathrm{min})$

Fat oxidation $(\mathrm{g} / \mathrm{min})=1.6946 \times \mathrm{VO}_{2}(\mathrm{~L} / \mathrm{min})-$ $1.7012 \times \mathrm{VCO}_{2}(\mathrm{~L} / \mathrm{min})$

138 • Jurnal Gizi Klinik Indonesia, Vol. 11, No. 3, Januari 2015

\section{Statistical analysis}

Statistical analysis was performed using the Statistical Analysis System (version 9.2, SAS Institute Inc, Cary, NC). Analysis of variance (ANOVA) for repeated measurements was performed to test the timing effect for differences along the experiment in REE, TEF, and substrate oxidation. A paired t-test was used to compare the differences of the measured parameters between two meals. The postprandial response of the serial measurements of TEF were summarized, and the areas under the curve (AUC) or above the curve (AAC) were calculated using the trapezoid rule (12). The AUCs adjusted for baseline values were calculated by subtracting the values in the fasting state from each postprandial value. The level of significance was set at $P$-values less than 0.05 .

\section{RESULTS}

Ten subjects participated in and completed the study. All data concerning anthropometric measurements are summarized in Table 2. The mean age and BMI were $20.8 \pm 1.2$ years and $21.3 \pm 3.4 \mathrm{~kg} / \mathrm{m} 2$, respectively. Based on the World Health Organization's criteria (2), one subject was classified as obese.

The fasting and postprandial energy expenditures are shown in Table 3. Repeated ANOVA measurements showed significant differences in REE between before and after the ingestion of two meals. Postprandial energy expenditure in chicken meals decreased relatively similar to the fasting state at $330 \mathrm{~min}$, which was faster than those who received a tofu meal (at $360 \mathrm{~min}$ ). Thermic effect of food was different between the two meals at the early measurement time. The chicken meal was significantly more thermogenic at $30 \mathrm{~min}(\mathrm{kcal} / \mathrm{min})$ than the tofu meal (kcal/min) (Figure 1). Both of the meals reached the maximum point of TEF at $60 \mathrm{~min}$.

Figure 2 shows the amount of TEF in different analyses. The area under the curve representing the total TEF over 6 hours was higher (not significant) in chicken in the tofu meals $(47.79 \mathrm{kcal}$ vs. $44.78 \mathrm{kcal} ; P=0.51)$. The percentage of energy intake as TEF in both meals was not $\operatorname{different}(P=0.51)$; it was $12.6 \%$ and $11.39 \%$ for chicken and tofu meals, respectively. Similarly, the percentage of 
A Fahmy Arif Tsani, dkk: Thermogenic effect and substrate oxidation of protein from animal and plant sources in adults

Table 2. Characteristics of the subjects

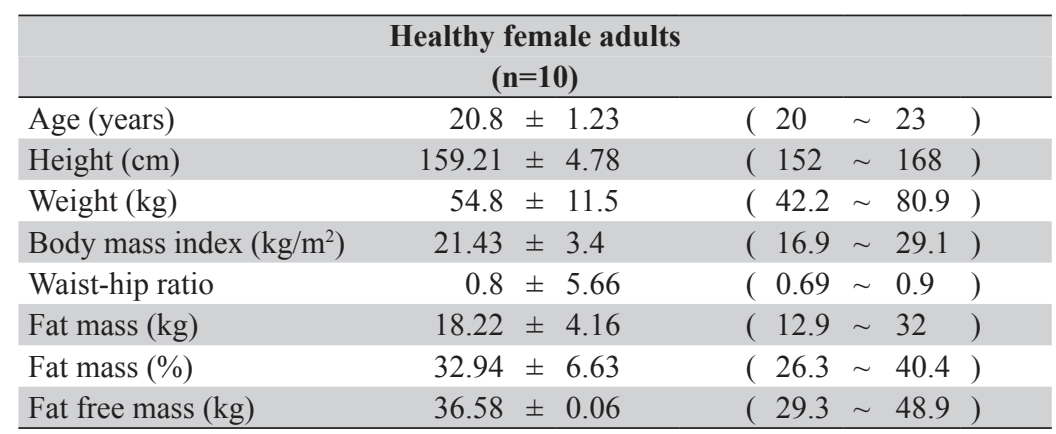

Table 3. Preprandial and postprandial energy expenditures of two meals

\begin{tabular}{|c|c|c|c|c|c|c|c|}
\hline \multirow[b]{2}{*}{ Preprandial state } & \multicolumn{3}{|c|}{$\begin{array}{l}\text { Chicken meal } \\
\text { (animal-based) }\end{array}$} & \multicolumn{3}{|c|}{$\begin{array}{c}\text { Tofu meal } \\
\text { (plant-based) }\end{array}$} & \multirow[t]{2}{*}{ Difference } \\
\hline & 1297.16 & \pm & 171.74 & 1281 & \pm & 138.1 & \\
\hline \multicolumn{8}{|l|}{ Postprandial state } \\
\hline $30 \mathrm{~min}$ & 1533.93 & \pm & $229.87 * * 1)$ & 1459 & \pm & $154.23 *$ & $0.0176(\mathrm{~S})^{2)}$ \\
\hline $60 \mathrm{~min}$ & 1548.52 & \pm & $214.86^{* *}$ & 1514 & \pm & $165.36^{*}$ & 0.466 (NS) \\
\hline $90 \mathrm{~min}$ & 1530.12 & \pm & $193.58 * *$ & 1507 & \pm & $178.39 * *$ & $0.801(\mathrm{NS})$ \\
\hline $120 \mathrm{~min}$ & 1523.83 & \pm & $199.24 * *$ & 1495 & \pm & $202.64 * *$ & $0.6652(\mathrm{NS})$ \\
\hline $150 \mathrm{~min}$ & 1512.54 & \pm & $219.21 * *$ & 1475 & \pm & $184.48 * *$ & $0.507(\mathrm{NS})$ \\
\hline $180 \mathrm{~min}$ & 1493.35 & \pm & $216.01 * *$ & 1462 & \pm & $171.88^{*}$ & $0.7001(\mathrm{NS})$ \\
\hline $210 \mathrm{~min}$ & 1492.83 & \pm & $232.55 * *$ & 1464 & \pm & $186.6^{*}$ & $0.7549(\mathrm{NS})$ \\
\hline $240 \mathrm{~min}$ & 1469.26 & \pm & $241.48 * *$ & 1459 & \pm & $175.35^{* *}$ & 0.6995 (NS) \\
\hline $270 \mathrm{~min}$ & 1455.38 & \pm & $216.42 *$ & 1446 & \pm & $169.51 * *$ & $0.7074(\mathrm{NS})$ \\
\hline $300 \mathrm{~min}$ & 1436.09 & \pm & $218 *$ & 1426 & \pm & $184.06^{*}$ & $0.7469(\mathrm{NS})$ \\
\hline $330 \mathrm{~min}$ & 1447.66 & \pm & 214.94 & 1419 & \pm & $192.26^{*}$ & $0.643(\mathrm{NS})$ \\
\hline $360 \mathrm{~min}$ & 1416.35 & \pm & 194.85 & 1402 & \pm & 179.54 & $0.9097(\mathrm{NS})$ \\
\hline
\end{tabular}

${ }^{1)}$ Significantly different by repeat ANOVA t-test between preprandial and postprandial state;

2) $\mathrm{S}=$ significant; $\mathrm{NS}=$ not significant based on Paired t-test between chicken and tofu meal;

$*=\mathrm{p}<0.05 ; * *=\mathrm{p}<0.01$

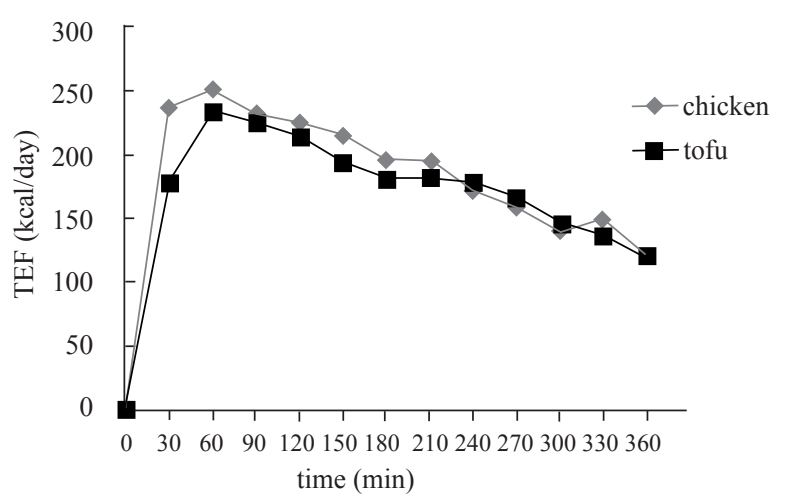

Figure 1. Thermic effect curve of chicken and tofu meal

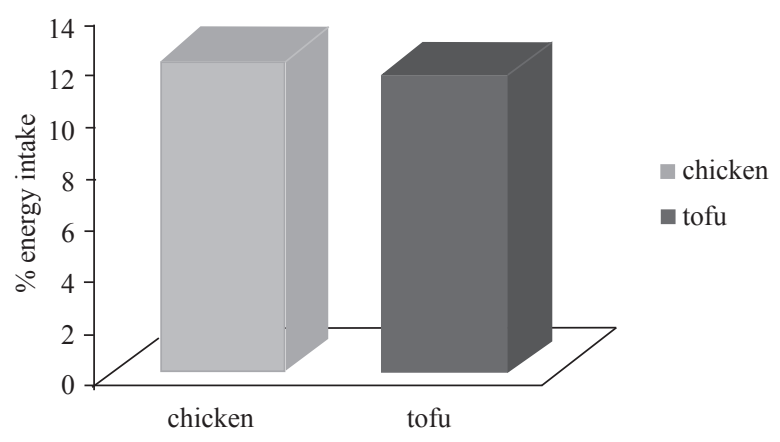

Figure 2. Area under curve (AUC) of TEF during 6 hours measurements 
resting energy expenditure as $\operatorname{TEF}(14.62 \%$ vs. $13.97 \%$, $P=0.71)$, TEF per weight ( $0.87 \mathrm{vs} .0 .82 \mathrm{kcal} / \mathrm{kg}, P=0.53)$, and TEF per fat-free mass ( $1.3 \mathrm{vs} .1 .21 \mathrm{kcal} / \mathrm{kg}, P=0.5)$ were also not significantly different in the two meals.

Substrate oxidation is described in Figure 3. No differences were observed in the carbohydrate oxidation $(\mathrm{P}=0.45)$, fat oxidation $(\mathrm{P}=0.75)$, and protein oxidation $(\mathrm{P}=0.24)$ of both meals. The postprandial carbohydrate oxidation rate was lower than before the consumption of the meals. However, the decreased value of the chicken meal was not significant $(P=0.07)$. Conversely,

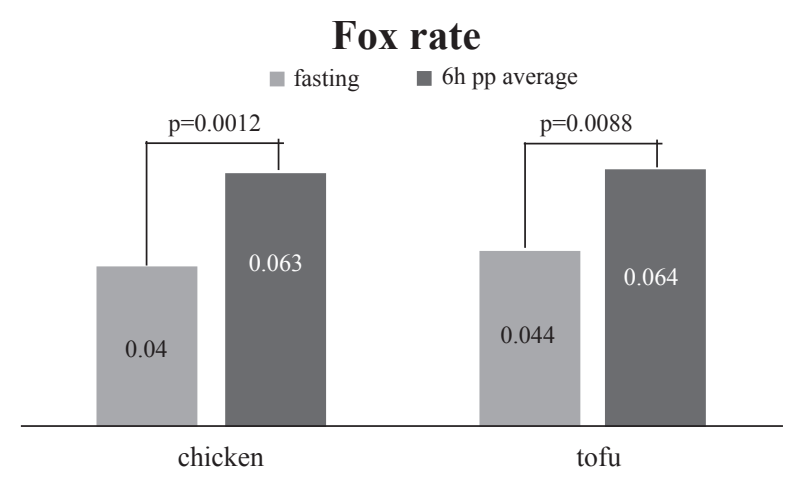

\section{Carbohydrate oxidation rate}
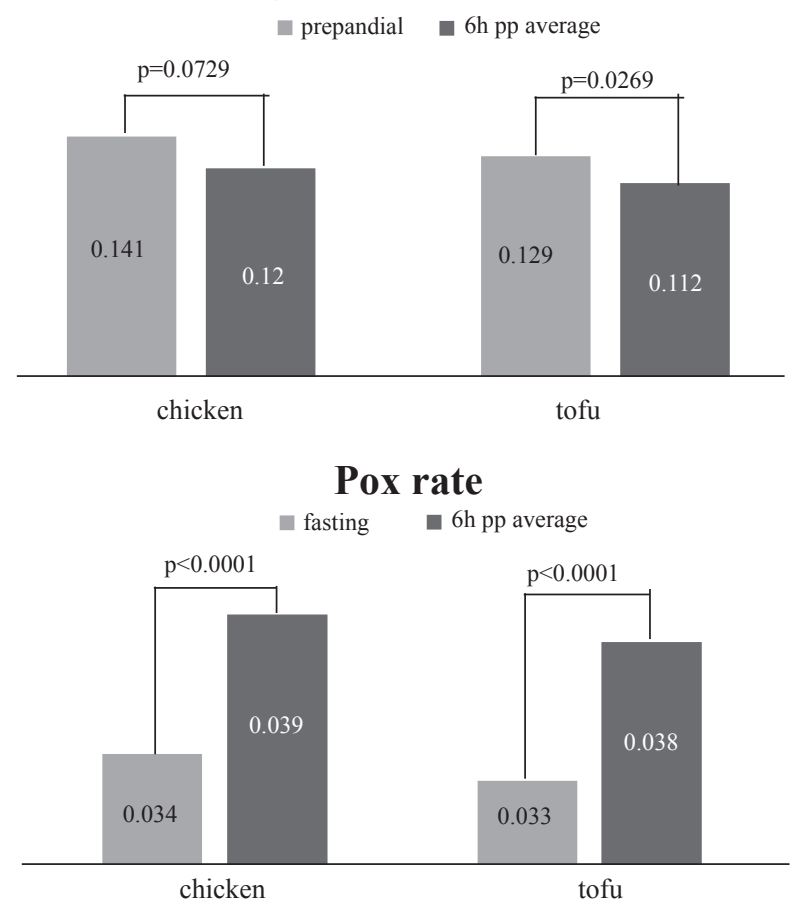

Figure 3. Change of substrate oxidation carbohydrate oxidation rate, fat oxidation rate, and protein oxidation rate postprandial fat and protein oxidation were significantly higher than in the fasting state in both meals $(P<0.01$ and $P<0.001$ in the chicken and tofu meals, respectively). Repeated ANOVA analyses showed that postprandial carbohydrate and fat oxidation were relatively similar to the fasting state at $330 \mathrm{~min}$ in both meals, while the postprandial protein oxidation reached a similar point as the fasting state at $360 \mathrm{~min}$.

\section{DISCUSSION}

In the present study, animal- and plant-based diets induced a relatively similar level of energy expenditure. The thermic effect of both meals were determined to be similar based on total measurement, energy intake-adjusted, REEadjusted, body weight-adjusted, and fat-freemass-adjusted values. This result could be due to both meals having a high protein content, which induced higher TEF compared to other macronutrients. Studies of human energy metabolism consistently report higher energy expenditure following the consumption of meals with high protein content (13). Contrary to this finding, observed that a high animal protein diet produced a greater increase $(1.9 \%)$ in total energy expenditure thana high plant protein diet (5). This could be caused by the different sources of animal protein that were used. They used pork meal as the animal protein-based diet instead of chicken meal.

Chicken and tofu are two foods with a high protein composition. This study hypothesized that the use of chicken could stimulate higher effects on energy expenditure. However, we did not observe any not significant differences in energy expenditures between the two meals due to a similar effect of thermogenesis. This insignificant postprandial thermogenesis could be caused by a similar content of amino acids between the two meals. A study reported that a well-balanced amino acid mixture produced a higher thermogenic response than an amino acid mixture with a lower biological value (5). Furthermore, the results from animal studies suggested that leucine is particularly thermogenic compared with other amino acids (14).

This study hypothesized that only a small contribution fromthe fat content in the meals could influence the thermic effect due to the low percentage of fat in both meals, which was $27 \%$ of the energy intake. 
Furthermore, fat has the lowest thermic effect for separate macronutrients, which ranged from $0 \%$ to $3 \%(15)$.

The thermic effect of the tofu meal stopped at 360 min, while thermic effect of the chicken meal disappeared at $360 \mathrm{~min}$. Conversely, the thermic effect of the chicken meal was significantly higher than the tofu meal at $30 \mathrm{~min}$. This could be evidence that although both of the meals hada similar effect on energy expenditures, animal protein had a more acute effect than that of a plant protein-based diet.

This study showed that chicken and tofu meals did not differ in substrate oxidation. Fat and protein oxidation increased after ingestion of the meals. Protein oxidation lasted longer (at $360 \mathrm{~min}$ ) than carbohydrate and fat oxidation (at $330 \mathrm{~min}$ ). This result suggests that a high protein diet influenced the higher macronutrient oxidation rate (11). The differences were only observed in the pattern of increased substrate oxidation after ingestion. The increased carbohydrate, fat, and protein oxidation rates of the chicken meal were relatively faster than those of the tofu meal. This could be caused by a more acute thermic effect of the chicken meal than the tofu meal.

\section{CONCLUSIONS}

In conclusion, the present study has shown that TEF and substrate oxidation are not significantly different between animal- and plant-based protein diets. However, animal-based protein diets exerted a more acute thermic effect than plant protein-based diets. These similar effects could be strongly caused by the same texture and amino acid compositions of the diets.

Our future work entails exploring additional studies that are related to this finding. Exploring various age groups and genders with adjustments based on body composition and physical activity could be an alternative for obtaining the true thermic effect of a high protein diet, which could be relevant for weight loss programs.

\section{ACKNOWLEDGEMENT}

This research was supported by Basic Science Research Program through the National Research Foundation of Korea (NRF) funded by the Ministry of Education, Science and Technology (2010-0004472).
The authors gratefully acknowledge the resources that were provided by Gangneung-Wonju National University under the Department of Food and Nutrition. The authors would also like to thank the subjects and investigators for their participation in this study.

\section{Declaration of Interest Statement}

The authors declare that there are no known conflicts of interest associated with this publication.

\section{REFERENCES}

1. Swinburn BA. Caterson I, Seidell JC, James WP. Diet, nutrition, and the prevention of exces weight gain and obesity. Public Health Nutr 2004;7:123-46.

2. WHO Consultation on Obesity. Obesity-preventing and managing the global epidemic. Geneva: World Health Organization; 2000.

3. Schiff WJ. Nutrition for healthy living. New York: McGraw-Hill; 2009.

4. Schutz Y, Bessard E, Jequer E. Diet-induced thermogenesis measured over a whole day in obese and nonobese women. Am J Clin Nutr 1984;40:545-52.

5. Mikkelsen PB, Toubro S, Astrup A. Effect of fat-reduced diets on 24-h energy expenditure: comparisons between animal protein, vegetable protein, and carbohydrate. Am J Clin Nutr 2000;72:1135-41.

6. Hochstenbach-Waelen A, Westerterp-Plantenga MS, Veldhorst MA, Westerterp KR. Single-protein casein and gelatin diets affect energy expenditure similarly but substrate balance and appetite differently in adults. J Nutr 2009:129(12):2285-92.

7. Abete I, Astrup A, Martínez JA, Thorsdottir I, Zulet MA. Obesity and the metabolic syndrome: role of different dietary macronutrient distribution patterns and specific nutritional components on weight loss and maintenance. Nutr Rev 2010;68(4):214-31.

8. Dubois D, Dubois EF. The measurements of the surface area of man. Archiv Intern Med 1915;15:868-81.

9. Weir JDV. New methods for calculating metabolic rate with special reference to protein metabolism. J Physiol 1949;109:1-9.

10. Ravussin E, Swinburn BA. Energy expenditure and obesity. Diabetes Rev 1996;4:403-22.

11. Tentolouris N, Pavlatos S, Kokkinos A, Perrea D, Pagoni S, Katslambros N. Diet-induced thermogenensis and substrate oxidation are not different between lean and obese women after two different isocaloricmelas, one rich in protein and one rich in fat. J Metabol 2008;57:313-20. 
12. Matthews JN, Altman DG, Campbell MJ, Royston P. Analysis of serial measurements in medical research. BMJ 1990;300:230-5.

13. Halton TL, Hu FB. The effects of high protein diets on thermogenesis, satiety and weight loss: a critical review. J Am Coll Nutr 2004;23:373-85.
14. Tsujinaka T, Sakaue M, Iijima S, Ebisui C, Kan K, Kishibuchi M, Morimoto T, Kido Y. Modulation of thermogenic response to parenteral amino acid infusion in surgical stress. Nutrition 1996;12(1):36-9

15. Tappy L. Thermic effect of food and sympathetic nervous system activity in humans. Reprod Nutr Dev 1996;36(4):391-7. 